\title{
A REVIEW ESSAY
}

\section{J.M. ROBERTS AND SUSAN WISE BAUER: TWO GREAT HISTORIANS, TWO DIFFERENT APPROACHES}

\author{
Chris Edwards \\ Fishers High School \\ Fishers, Indiana
}

Susan Wise Bauer. The History of the Ancient World: From the Earliest Accounts to the Fall of Rome. New York: W.W. Norton, 2007. Pp. 896. Cloth, \$35. ISBN: 9780393059748.

Susan Wise Bauer. The History of the Medieval World: From the Conversion of Constantine to the First Crusade. New York: W.W. Norton, 2010. Pp. 746. Cloth, \$35. ISBN: 978-0393059755.

Susan Wise Bauer. The History of the Renaissance World: From the Rediscovery of Aristotle to the Conquest of Constantinople. New York: W.W. Norton, 2013. Pp. 816. Cloth, \$35. ISBN: 978-0393059762.

J.M. Roberts. The History of the World. Sixth ed. Oxford: Oxford University Press, 2013. Pp. 1280. Cloth, \$45. ISBN 978-0199936762.

Most historians, and therefore most history books, focus on relatively manageable topics such as wars, social movements, or (increasingly) commodities and technologies. Not many decide to spend a career writing the history of the world. The scarcity of historical writers who make the attempt to write a thorough world history, therefore, makes the recent publication of a new sixth edition of J.M. Roberts' The History of the World (2013) and the first three volumes of a history of the world, entitled The History of the World: From the Earliest Accounts to the Fall of Rome (2007), The History of the Medieval World: From the Conversion of Constantine to the First Crusade (2010), and The History of the Renaissance World: From the Rediscovery of Aristotle to the Conquest of Constantinople (2013), by Susan Wise Bauer all the more important. For teachers of world history, the authors each offer very different scholarly approaches to the discipline that are useful in different ways. Where Roberts offers grand connections, Bauer offers specifics; where Roberts focuses on Western Civilization, Bauer provides rigorous balance with the civilizations of Islam and East Asia; and where Roberts occasionally sails high above his source material, Bauer reminds her readers constantly of how closely tied her narrative is to classical sources.

Since Bauer has written three volumes so far, enough material exists to discuss the different tactics used by the authors. The differences to Roberts exist throughout 
Bauer's work, but for the sake of brevity, I will use only three examples. The single Roberts volume will be compared with excerpts from each of the three Bauer books.

When Roberts writes about ancient Sumer, he summarizes the content and keeps his material hidden:

Sumerian civilization had deep roots. The people had long shared a way of life not very different from that of their neighbors. They lived in villages and had a few important cult centres which were continuously occupied. One of these, at a place called Eridu, probably originated in about $5000 \mathrm{BC}$. It grew steadily well into historic times and by the middle of the fourth millennium there was a temple which some have thought to have provided the original model for Mesopotamian monumental architecture ... (p. 52).

Bauer's approach is more specific and she cites the source material in her text:

After the Great Flood, the Sumerian king list tells us that the city of Kishto the north, surrounded by cornfields-became the new center of kingship. The list begins over again, with a series of kings generally known as "The First Dynasty of Kish." The first ruler of Kish was a man called Gaur; next came the magnificently named Fulla-Ndapa-annapad; after that, another nineteen kings led right down to Enmebarggesi, the twenty-second king after the flood. Thanks to inscriptions, we know that Emmebaraggesi ruled around 2700, the first date that we can assign to a Sumerian king (p. 17).

The treatment of non-European civilizations represents the most striking difference between the world history of Roberts and that of Bauer. The sixth edition of Roberts contains 36 chapters, and 22 are arguably about Europe and the West. Bauer's work is rigorously chronological and balanced. Her chapters are short, and each ends with a graphic timeline showing the key events from each region discussed. On page 214 of The History of the Medieval World, for example, Bauer provides a timeline including the major events in Arabia, the Persian Empire, Byzantium, and Western Europe.

Roberts devotes about three pages (from 438-441) to China's Sui Dynasty whereas Bauer devotes seven (pp. 223-230) in The History of the Medieval World, including a timeline. Roberts writes from the sky when talking about the Sui collapse:

One reason for the trouble was overstretch in terms of wars. A conflict with Vietnam in the first decade of the seventh century ended badly, as conflicts with Vietnam often do. A war in Korea also ended badly. The Sui had clearly overreached themselves ... (p. 440). 
In her second volume; Bauer writes from the ground on the same topic:

[Yangdi] grew obsessed with completing the conquest of Goguryeo, pouring the remaining treasury into it and sending troops into the Korean peninsula over the bodies of their fallen comrades. The war had now dragged on for nearly twenty years; the standing Sui army of three hundred thousand soldiers had been reduced to less than three thousand.

Sui Yangdi drafted, conscripted, and enslaved enough men for one final push. In 612 , he took an army reported to be more than a million men strong into tiny Goguryeo, where Eulji Mundeok made his stand at the capital city Pyongyang. In a fierce, epically bloody battle, the Korean soldiers surrounded and obliterated the Chinese troops (p. 229).

Finally, Bauer constantly presents fragments of source material for the reader in her narrative, something Roberts almost never does. Consider their different treatments of the Fourth Crusade. Roberts writes:

The fatal blow came in 1204, when Constantinople was at last taken and sacked, but by Christians, not the pagans who had threatened it so often. A Christian army which had gone east to fight the infidel in a fourth crusade was turned against the empire by the Venetians. It terrorized and pillaged the city (this was when the bronze horses of the Hippodrome were carried off to stand, as they did until the early 1980s, in front of St. Mark's cathedral in Venice), and enthroned a prostitute in the patriarch's seat in St. Sophia (p. 373).

In The History of the Renaissance World, Bauer's narrative presents the reader with the source material:

On the morning of April 13, Constantinople lay under Crusader control, and the Crusaders began to strip the city clean. "Gold and silver, tableservices and precious stones, satin and silk," writes Villehardouin, "mantles of squirrel fur, ermine and miniver, and every choice thing to be found on this earth ... (p. 180).

Bauer goes on to include a full paragraph from this account and then another full paragraph from an Islamic source about the same event. Only rarely does a reader encounter an historical writer who makes such extensive use of primary evidence.

World history as a subject remains a relatively young field. One might trace its origins to the 1922 publication of $A$ Short History of the World by H.G. Wells, who is better remembered for his imaginative science fiction. Roberts published the first 
edition of The History of the World in 1976 and spent much of the rest of his life updating and revising the work. Shorter versions of the original were published, as were sections dealing only with Europe. Roberts, an Oxford professor, became a recognizable public figure in Britain when he presented his ideas about Western history on a BBC documentary in the mid-1980s.

Roberts' work did more to popularize world history than any other. His book, despite its intimidating page count, sold over a million copies. The gaps he left, chronicled above, have more to do with a lack of source material than a lack of scholarship. O.A. Westad, the editor of the sixth edition, explains in his introduction that Roberts continued updating his world history and was in the process of adding more about Eastern history when he died in 2003. Westad's additions to the sixth edition mostly include the addition of material only recently available to historians about Eastern and Islamic societies.

Because of the relative youth of world history as a discrete approach, and because of the incompleteness of the Roberts text, it is tempting, then, to look at Bauer's work as another step in the evolution of world history. Her work is undoubtedly more comprehensive, her story more detailed, and her mastery of the source material more impressive. I would caution against that interpretation, however. Although both Roberts and Bauer wrote for a general audience, they seemed to have different aims. We might understand the Roberts book as being character driven, and the West features as the protagonist. Bauer's volumes are plot-driven and lack a central character. The story is the main character, and she is not constrained by the single-volume format as Roberts was.

Twelve years ago, upon learning that I had procured a position as a seventh-grade teacher of world history, I hustled to the bookstore and discovered the Roberts text. That year, when budget cuts had eliminated my textbooks, I relied on Roberts almost exclusively for my content area knowledge (inexplicably, I had been given a license to teach world history without ever having had a course on the topic as a whole). That year, I treated The History of the World with a reverence that people normally reserve for holy books. More recently, I bought a copy to give to my first student teacher upon her departure.

But now I teach Advanced Placement World History, and my content-area knowledge is in a different place. AP World History leans toward the East, and Bauer's approach to her subject with its geographic balance and detailed explanations, proves more valuable to me now. Bauer and Roberts complement each other, and I return constantly to both authors for content area guidance when shaping my lesson plans, which is this teacher's compliment to them both. 